\title{
PREFERENSI SISWA SMA TERHADAP CIRI-CIRI PERILAKU GURU
}

\author{
Oleh: Triyono ${ }^{1}$
}

\begin{abstract}
Abstrak
Tugas utama guru adalah mendidik, mengajar, dan membimbing; sehingga untuk menjadi seorang guru dituntut memiliki persyaratan tertentu. Pemerintah telah menetapkan persyaratan untuk menjadi guru antara lain berpendidikan minimal Sarjana atau Diploma IV serta memiliki kompetensi profesional, pedagogik, kepribaian, dan kompetensi sosial. Apakah persyaratan itu telah sesuai dengan harapan siswa, melalui penelitian ini diungkap ciri-ciri perilaku guru yang dikehendaki oleh siswanya.

Penelitian dilakukan terhadap 304 siswa yang tersebar di 5 SMAN di kabupaten Klaten. Data dikumpulkan melalui kuesioner yang terdiri dari 75 butir pertanyaan tentang ciri perilaku guru yang disenangi dan yang tidak disenangi siswa. Data yang terkumpul dianalisis menggunakan analisis faktor dengan bantuan program SPSS.

Hasil penelitian menemukan (1) terdapat dua puluh tujuh ciri perilaku guru yang dikehendaki oleh siswanya dan dapat dikelompokkan menjadi delapan faktor yakni: tekun, disiplin, modern, perhatian, profesional, humoris, aktif, dan tampil rapi; dan (2) terdapat dua belas ciri perilaku guru yang tidak dikehendaki oleh siswanya dan dapat dikelompokkan ke dalam empat faktor yakni pemalas, pemarah, sering menghukum, dan sering terlambat.
\end{abstract}

Kata kunci: preferensi siswa, perilaku guru

\section{Pendahuluan}

Jabatan guru minimal mendeskripsikan tugas, sikap, dan perilaku seorang guru dan harapan-harapan dari berbagai pihak terhadap seorang guru. Winarno Surahmad (1969) mengemukakan bahwa guru memiliki tugas khusus, sebab mereka ditugaskan hidup dan berpijak pada realitas hari esok untuk menyiapkan anak didik agar dapat menemukan hari depannya. Secara garis besar, Gordon (1956) mengklasifikasikan tugas guru menjadi tiga jenis yaitu (1) guru sebagai pekerja kelompok yang menciptakan iklim belajar di dalam maupun di luar sekolah, (2) guru sebagai penyeluruh yang tugasnya membantu anak didik agar mampu menyesuaikan diri dalam lingkungan hidupnya, dan (3) guru sebagai pelaku penelitian di tengah-tengah situasi nyata dalam rangka memenuhi kebutuhan praktis untuk menciptakan situasi yang lebih baik. Bany dan Johnson (1975) membuat rumusan tugas utama seorang guru guru yang terdiri dari tiga hal pokok yakni: mengajar, mengevaluasi, dan memimpin.

Berdasarkan uraian tentang tugas jabatan guru sebagaimana dikemukakan di atas, jelas bahwa tugas guru menuntut dimilikinya pengetahuan, keterampilan, serta sikap dan

\footnotetext{
${ }^{1}$ Dosen Universitas Widya Dharma Klaten
} 
sifat tertentu agar seorang guru dapat menjalankan tugasnya dengan baik. Hal itu berarti pula tidak semua orang mampu melaksanakan tugas sebagai seorang guru. Oleh sebab itu penelitian ini berupaya mengungkapkan sejumlah perilaku guru yang dikehendaki dan diinginkan oleh para siswanya. Tugas utama seorang guru adalah mengajar, membimbing, dan tugas administrasi. Untuk bisa melaksanakan tugas tersebut diperlukan beberapa persyaratan baik dari aspek pribadi, kemampuan dalam melaksanakan tugas mengajar, maupun persyaratan dalam hubungannya dengan kemampuan berkomunikasi.

Pemerintah Republik Indonesia telah menetapkan sejumlah persyaratan bagi seorang guru melalui Undang-Undang Nomor 14 Tahun 2005 tentang Guru dan Dosen. Dalam Undang-Undang Nomor 14 Tahun 2005 tentang Guru dan Dosen maupun Pasal 1 ayat (1) Peraturan Pemerintah Nomor 74 Tahun 2008 tentang Guru dengan jelas dinyatakan bahwa guru adalah pendidik profesional dengan tugas utama mendidik, mengajar, membimbing, mengarahkan, melatih, menilai, dan mengevaluasi peserta didik pada pendidikan anak usia dini jalur pendidikan formal, pendidikan dasar, dan pendidikan menengah. Pernyataan ini sekaligus mengandung pengertian bahwa pemerintah telah mengakui "guru" sebagai pekerja professional, artinya guru merupakan kelompok pekerjaan yang menuntut keahlian tertentu dan keahlian tersebut diperoleh melalui pendidikan khusus; bukan karena menirukan dan bukan pula karena otodidak. Hal tersebut dapat dimaknai bahwa untuk menjadi seorang guru diperlukan keahlian atau kompetensi khusus, serta memiliki kualifikasi pendidikan tertentu.

Penelitian tentang perilaku guru yang dilakukan oleh Biddle Ellen (1974) mencakup perilaku pribadi dan sosial. Penelitian ini menyimpulkan bahwa ada 18 ciri perilaku guru yang dapat dikelompokkan ke dalam empat faktor yakni: hiperkritik, tanggap, responsible, dan kreatif. Pendekatan lain yang digunakan dalam mengamati perilaku guru ialah model Ryans (1960) yang menyimpulkan terdapat tiga dimensi perilaku guru yaitu: (a) ramah, pengertian, egosentris, (b) bertanggungjawab, praktikal, sistematis, teliti dan (c) stimulating dan imajinatif. Akan tetapi Good dan Bropy (1973) justru menemukan empat keterampilan khusus yang dibutuhkan guru dalam mengajar yakni: komunikasi, pembuatan model, pengelolaan dan pengelompokan.

Penelitian yang dilakukan oleh Murray, Rushton, dan Paunonen (1990) menyimpulkan ada 29 ciri perilaku guru yang dikelompokkan menjadi lima faktor yaitu: (1) berprestasi dan ekstraversi, (2) liberalism, neorotisis, dan efek negatif, (3) jujur, tulus, baik hati, (4) rapi dan berbicara nyaring, (5) pemberani dan sabar. Penelitian tersebut juga 
melaporkan bahwa situasi dan kondisi kelas yang diajar oleh guru dengan perilaku yang disenangi siswa, lebih akrab dan mampu memperoleh prestasi tinggi dibanding dengan situasi kelas yang diajar oleh guru dengan ciri perilaku yang tidak disukai oleh siswa.

Studi yang dilakukan oleh Nash (1974), mengidentifikasi harapan siswa terhadap perilaku guru dengan cara memberikan kartu yang telah tertulis nama guru yang mengajar di kelasnya beserta karakter yang diinginkan. Hasilnya menunjukkan bahwa ciri-ciri keberhasilan guru meliputi (1) kualifikasi pribadi, (2) pengelolaan kelas, (3) hubungan guru-siswa, (4) teknik mengajar, dan (5) sikap profesional.

Melalui penelitian ini akan diuji bahwa (1) sekurang-kurangnya terdapat lima belas ciri perilaku guru SMA yang dikehendaki oleh para siswanya yaitu: rajin (RJN), disiplin (DIS), hubungan sosial (SOS), Terbuka (BUK), tampil rapi (RAP), optimis (OPT), penyabar (SAB), humoris (HUM), objektif dalam meberikan nilai (OBJ), menguasai materi (MAT), variasi metode (MET), memberikan tugas (TUG), bekerja dengan teliti (TEL), bekerja mandiri (MAN), dan berwibawa (WIB); dan (2) kelima belas ciri perilaku guru SMA yang dikehendaki oleh para siswanya tersebut saling dependensi satu dengan yang lain dan dapat diklasterkan ke dalam empat faktor yaitu: ciri pedagodik, ciri pribadi, ciri profesional, dan ciri hubungan sosial.

\section{Metodologi}

Secara keseluruhan kegiatan penelitian ini dilaksanakan mulai Maret sampai dengan bulan Juli 2016; sedangkan pengambilan data dilakukan pada bulan Mei dan Juni 2016. Sebagai lokasi penelitian telah dipilih sejumlah SMA Negeri di kabupaten Klaten, tersebar di 5 (lima) Wilayah Pembantu Bupati atau eks Kawedanan yaitu: (1) eks kawedanan Gondangwinangun, (2) eks kawedanan Pedan, (3) eks kawedanan Delanggu, (4) eks kawedanan Jatinom, dan (5) eks kawedanan Klaten Kota. Secara administrasi, kabupaten Klaten terbagi atas 26 kecamatan dengan 401 desa/ kelurahan.

Secara substansif, objek penelitian ini ditelaah dengan pendekatan multidisiplin yakni psikologi dan pendidikan, sedangkan secara metodologi, objek penelitian ini dikerjakan dengan pendekatan multivariate dengan analisis faktor.

Ditinjau dari variabel-variabel yang dikumpulkan berupa fenomena yang tidak dapat dimanipulasikan serta merupakan perwujutan dari sikap dan perilaku responden, penelitian ini termasuk dalam tipe ex post facto. Akan tetapi bila dilihat dari teknik pengambilan data yang dilakukan dengan menggunakan kuensioer, penelitian ini juga disebut survei. Namun 
apabila dilihat dari permasalahan yang ditelah sebagai fenomena yang terjadi pada saat fenomena dilakukan, penelitian ini dapat disebut sebagai penelitian deskriptif.

Dengan mengingat bahwa populasi penelitiannya cukup besar, sedang pengambilan sampel secara metodologis dapat dipertanggungjawabkan, dalam penelitian ini akan ditetapkan sampelnya saja. Dengan melihat tabel Krejchie dan Morgan, untuk populasi sebanyak 11.597diperlakukan sampel minimal 378.

Dengan mempertimbangkan sebaran SMA yang ada, dalam penelitian ini digunakan multi-stages-random-sampling dalam memilih unit sampel sebagai responden. Dalam hubungan ini di setiap Wilayah Pembantu Bupati (Kawedanan) dipilih secara random satu SMA, kemudian dari setiap SMA yang terpilih itu dipilih secara random pula masingmasing tiga kelas; yakni 2 (dua) kelas X dan 1 (satu) kelas XI. Untuk kepentingan analisis multivariate, sampel sebesar 300 sudah cukup baik, sebagaimana dikemukakan oleh Comrey (1973) sebagai berikut "Correlation coefficients and to be less reliable when estimated from small samples. Therefore, it is important that sample size be large enough that correlations are reliable estimated. As a guide sample size of 50 a very poor, 100 as poor, 200 as affair, 300 as good, 100 as poor, and 1.000 as exellent.

Sedangkan Tabachnick dan Fidell (1983) menyarankan bahwa untuk berbagai tujuan analisis, sampel 100 sampai 200 sudah cukup baik, apabila viarians subjeknya homogen dan banyaknya variabel yang diteliti tidak begitu banyak, sebagaiman dikatakan sebagai berikut "A sample size of 100-200 is good enough for most purposes, particularly when subjects are homogeneous and number of variables is not too large".

Dengan berpedomaan pada kedua pendapat di atas, maka dengan menggunakan tabel Krejcie dan Morgan, dalam penelitian ini untuk memperoleh sampel minimum bisa dipertanggungjawabkan. Distribusi sampel penelitian menurut sekolah dan kelas dapat dilihat pada Tabel berikut.

Tabel-1. Sebaran Sampel Penelitian

\begin{tabular}{|c|l|c|c|c|}
\hline \multirow{2}{*}{ No. } & \multirow{2}{*}{ Nama Sekolah } & \multicolumn{2}{|c|}{ Kelas } & \multirow{2}{*}{ Jumlah } \\
\cline { 3 - 4 } & & $\mathrm{X}$ & $\mathrm{XI}$ & \\
\hline 1. & SMAN-1 Wonosari & 75 & 0 & 75 \\
\hline 2. & SMAN-1 Jogonalan & 11 & 21 & 33 \\
\hline 3. & SMAN-1 Karanganom & 52 & 9 & 61 \\
\hline 4. & SMAN-1 Polanharjo & 77 & 0 & 77 \\
\hline 5. & SMAN-1 Cawas & 52 & 7 & 59 \\
\hline & Jumlah & 267 & 37 & 304 \\
\hline
\end{tabular}


Dalam penelitian ini dilibatkan sebanyak 75 (tujuh puluh lima) butir pertanyaan dari 15 variabel yang tidak dibedakan sebagai variabel bebas maupun variabel tergantung. Hal ini disebabkan sesuai dengan analisis statistik yang dipilih yakni analisis faktor, dan tujuan penelitian itu sendiri yakni mencari ciri-ciri perilaku guru yang dikehendaki siswa, untuk menemukan variabel yang jumlahnya lebih sedikit dari pada variabel yang semula dalam bentuk faktor. Sebagaimana dikemukakan oleh Suryanto 1988) bahwa "analisis faktor adalah kajian kesaling ketergantungan antara variabel-variabel, dengan tujuan untuk menemukan himpunan variabel-variabel baru yang lebih sedikit jumlahnya dari variabel semula, dan yang menunjukkan mana di antara variabel-variabel semula itu yang merupakan faktor-faktor persekutuan. Model analisis faktor berasumsi bahwa setiap variabel semula itu terdiri atas dua bagian yaitu bagian umum dan bagian khusus.

Untuk mengumpulkan data kelima belas ciri perilaku guru yang diduga dikehendaki para siswanya itu, digunakan seperangkat instrumen model skala Likert yang memiliki 5 (lima) pilihan; masing-masing: Sangat Senang (SS), Senang (S), Tidak Tahu (TT), Tidak Senang (TS), dan Sangat Tidak Senang (STS). Indikator instrumen ciri-ciri perilaku guru SMA yang disenangi sebagaimana tampak pada Tabel berikut.

Tabel-2. Indikator Instrumen Ciri-ciri Perilaku Guru

\begin{tabular}{|c|l|llllllll|}
\hline No. & \multicolumn{1}{|c|}{ Variabel } & \multicolumn{7}{|c|}{ Nomor pertanyaan } \\
\hline 1. & Rajin (RJN) & 1, & 2, & 3, & 6, & 7, & 8 & \\
\hline 2. & Disiplin (DIS) & 4, & 5, & 22 & & & & \\
\hline 3. & Hubungan Sosial (SOS) & 9, & 10, & 12, & 13, & 15, & 16, & 71, & 74 \\
\hline 4. & Terbuka (BUK) & 14, & 17, & 18, & 19, & 68 & & \\
\hline 5. & Tampil Rapi (RAP) & 11, & 20, & 21 & & & & \\
\hline 6. & Optimis (OPT) & 23, & 24, & 25, & 26, & 27, & 63 & \\
\hline 7. & Penyabar (SAB) & 29, & 30, & 31 & & & & \\
\hline 8. & Humoris (HUM) & 32, & 33, & 45 & & & & \\
\hline 9. & Objektif (OBJ) & 28, & 34, & 35, & 38, & 39 & & \\
\hline 10. & Kuasai Materi (MAT) & 40, & 41, & 42, & 43, & 44 & & \\
\hline 11. & Kuasai Metode (MET) & 46, & 47, & 48, & 49, & 50, & 51, & 52, & 53 \\
& & 54, & 56, & 70, & 72, & 73, & 75 & \\
\hline 12. & Memberi tugas (TUG) & 36, & 37, & 55, & 69 & & & \\
\hline 13. & Bekerja Teliti (TEL) & 57, & 58, & 59, & 60 & & & \\
\hline 14. & Bekerja Mandiri (MAN) & 61, & 62, & 64 & & & \\
\hline 15. & Berwibawa (WIB) & 65, & 66, & 67 & & & & \\
\hline
\end{tabular}

Catatan: Instrumen lengkap pada Lampiran-1

Dari indikator-indikator itu, kemudian dikembangkan sejumlah butir pertanyaan baik dalam bentuk pernyataan positif maupun pernyataan negatif. Sebagai pedoman dalam 
memberikan skor setiap jawaban responden. Setiap pertanyaan diberi rentang skor 1 sampai 5 tergantung dari arah pertanyaan. Tingkat preferensi siswa terhadap ciri-ciri perilaku guru ditujukkan oleh skor masing-masing pilihan jawaban sebagai ciri-ciri variabel guru yang dikehendaki siswa.

Dengan mengacu kepada tujuan penelitian ini, data yang dikumpulkan melalui penelitian ini dianalisis menggunakan analisis faktor (factor analysis). Analisis faktor termasuk analisis multivariate yang bertujuan meringkas atau mereduksi variabel yang diteliti secara keseluruhan (dalam penelitian ini sebanyak 15 variabel) yang diduga dapat dikelompokkan ke dalam beberapa variabel atau dimensi baru yang jumlahnya lebih sedikit, tetapi mampu mengekspresikan variabel utama (Yamin dan Kurniawan, 2014: 179). Analisis faktor bertujuan meringkas data dari sekelompok variabel yang saling berkolerasi satu sama lain; sedangkan konfirmasi dibentuk untuk menguji hipotesis (Tabachnick, 1983).

Menurut Hair, Anderson, Tatham, dan Black, 1995: 289) dalam analisis faktor dikenal dua pendekatan utama yaitu: analisis faktor eksplorasi (exploratory factor analysis), dan analisis faktor konfirmasi (confirmatory factor analysis). Analisis faktor eksplorasi digunakan apabila banyaknya faktor yang akan dibentuk tidak ditentukan terlebih dahulu; sedangkan analisis faktor konfirmasi digunakan jika banyaknya faktor yang terbentuk telah ditetapkan terlebih dahulu. Dalam penelitian ini digunakan analisis faktor eksplorasi, karena peneliti tidak menentukan banyaknya faktor yang terbentuk dari sejumlah variabel yang diteliti.

Asumsi dasar penggunaan analisis faktor bahwa variabel-variabel yang dianalisis dalam penelitian tidak dibedakan antara variabel bebas (independent variables) maupun variabel terikat (dependen variables), akan tetapi variabel-variabel tersebut memiliki keterkaitan atau saling berhubungan satu dengan yang lainnya (Suryanto, 1988).

Tahapan-tahapan dalam analisis faktor dimulai dari: pemilihan dan pengukuran kelompok variabel, penyusunan matriks korelasi, menentukan banyaknya faktor yang dipertimbangkan, ekstraksi faktor dari matriks kolerasi, rotasi faktor, dan interprestasi hasil. Secara matematika, analisis faktor akan menghasilkan beberapa kombinasi linier dari beberapa variable yang diteliti; kombinasi linier ini biasa disebut sebagai faktor (Tabachnick 1988). 
Pada Tabel-3 disajikan hasil analisis SPSS yang memperlihatkan sebanyak 20 butir instrumen memiliki sebaran data yang menyimpang dari distribusi normal sehingga digugurkan dan tidak diikutkan dalam analisis selanjutnya.

Tabel-3. Butir Instrumen yang tidak Valid Hasil Uji Normalitas

\begin{tabular}{|c|c|l|c|c|}
\hline $\begin{array}{c}\text { Nomor } \\
\text { urut }\end{array}$ & $\begin{array}{c}\text { Nomor } \\
\text { butir }\end{array}$ & \multicolumn{1}{|c|}{ Variabel } & Skewness & Kortusis \\
\hline 1. & 2 & Masuk kelas sesuai jadwal & $-1,941$ & 5,580 \\
\hline 2. & 9 & Bersikap ramah & $-1,794$ & 4,892 \\
\hline 3. & 18 & Menerima kekurangan siswa & $-1,656$ & 4,227 \\
\hline 4. & 21 & Sederhana, tidak berlebihan & $-1,089$ & 3,390 \\
\hline 5. & 23 & Banyak ide dan inisiatif & $-1,195$ & 2,608 \\
\hline 6. & 31 & Cepat dan mudah marah & 1,430 & 2,041 \\
\hline 7. & 36 & Membahas soal-soal yang sulit & $-1,766$ & 4,096 \\
\hline 8. & 39 & Adil dalam memberi nilai & $-1,678$ & 4,221 \\
\hline 9. & 42 & Menerangkan dengan jelas & $-2,323$ & 6,642 \\
\hline 10. & 43 & Memberikan catatan wkt mengajar & $-1,270$ & 2,475 \\
\hline 11. & 44 & Marah jika siswa bertanya & 1,783 & 3,657 \\
\hline 12. & 45 & Diselingi humor waktu mengajar & $-1,933$ & 4,907 \\
\hline 13. & 47 & Memelihara suasana kelas & $-1,144$ & 2,158 \\
\hline 14. & 54 & Memberi kesempatan bertanya & $-1,346$ & 2,773 \\
\hline 15. & 61 & Bertanggung jawab & $-1,336$ & 2,186 \\
\hline 16. & 63 & Berpandangan jauh ke depan & $-1,179$ & 2,222 \\
\hline 17. & 64 & Berani menanggung risiko & $-1,226$ & 2,810 \\
\hline 18. & 65 & Berwibawa, kharismatik & $-1,283$ & 2,605 \\
\hline 19. & 68 & Mampu menampung keluhan & $-1,279$ & 2,529 \\
\hline 20. & 74 & Pergaulan baik dengan siswa & $-1,427$ & 3,722 \\
\hline
\end{tabular}

Catatan: Kriteria kelayakan analisis jika Kurtosis $<3,000$

Nilai KMO and Bartlett's Test untuk korelasi antarvariabel yang diinginkan adalah > 0,500. Dari hasil analisis terhadap data yang dikumpulkan, diperoleh nilai KMO sebesar 0,813 yang artinya lebih besar dari 0,500 . Sementara itu, signifikansi yang dihasilkan dari Bartlett's Test of Sphericity adalah $<0,01$.

Tabel-4. Klasifikasi Indeks KMO

\begin{tabular}{|c|c|l|l|}
\hline No. & Indeks KMO & \multicolumn{1}{|c|}{ Sebutan } & \multicolumn{1}{c|}{ Keterangan } \\
\hline 1. & $>0,90$ & Marvelous & Menakjubkan \\
\hline 2. & $0,80-0,90$ & Meritorious & Berfaedah \\
\hline 3. & $0,70-0,80$ & Middling & Cukup \\
\hline 4. & $0,60-0,70$ & Mediacore & Kurang \\
\hline 5. & $0,50-0,60$ & Miserable & Sangat Kurang \\
\hline 6. & $<0,50$ & Unacceptable & Tidak bisa diterima \\
\hline
\end{tabular}

Sumber: Sofyan Yamin dan Kurniawan, 2014 
Nilai KMO tersebut akan meningkat apabila (1) jumlah ukuran sampel bertambah, (2) rata-rata koefisien korelasi bertambah, dan (3) jumlah variabel bertambah atau jumlah faktor berkurang. Setelah dilakukan pemeriksaan terhadap indeks KMO dan Uji Barlett's, dilakukan juga pemeriksaan terhadap nilai Anti-image-correlation yang ditunjukkan oleh nilai diagonal dari kiri atas ke kanan bawah pada setiap nilainya (nilai Measures Sampling Adequacy $=M S A$ ). Jika nilai MSA lebih kecil dari 0,50 maka variabel tersebut digugurkan (drop) dari sistem analisis faktor. Berdasarkan hasil analisis SPSS terdapat 2 (dua) pertanyaan yang memiliki nilai MSA lebih kecil dari 0,500 yakni pertanyaan nomor 5 dengan MSA $=0,462)$ dan pertanyaan nomor 33 dengan nilai MSA $=0,359$. Dengan demikian kedua pertanyaan tersebut digugurkan dan tidak diikutkan dalam analisis selanjutnya.

Tabel Communalities menjelaskan berapa persen (\%) faktor atau variabel baru yang terbentuk dari analisis faktor dapat menjelaskan varians (variance explained) dari variabel semula. Hasil analisis SPSS dari data ini menunjukkan nilai MSA untuk Anti-Image Correlation Matrix berada pada kisaran 0,551 (datang ke sekolah hanya waktu mengajar saja) sampai dengan 0,897 (mengaktifkan siswa dalam proses pembelajaran) sehingga dinyatakan layak untuk dianalisis menggunakan analisis faktor.

MSA menentukan apakah variabel-variabel independen bisa dikelompokkan ke dalam satu atau beberapa faktor. Jadi ketujuh puluh lima variabel independen akan dilihat apakah sesungguhnya bisa disederhanakan dan diklasterkan menjadi satu atau beberapa faktor yang saling tidak tumpang tindih.

Cara melakukannya adalah klik Analyze $>$ Data Reduction $>$ Factor... $>$ Pada Factor Analysis masukkan seluruh variabel independen ke kotak Variables $>$ Klik tombol Extraction... > Pada kotak dialog Factor Analysis: Extraction > Pada Method pilih Principal of components $>$ Ceklis Correlation Matrix $>$ Pada Display ceklis Unrotated factor solution dan Scree Plot $>$ Eigenvalues oves biarkan bernilai 1, sehingga variabel yang punya angka Eigenvalues $<1$ akan dikeluarkan $>$ Maximum Iterations for Convergence tetap pada angka $25>$ Klik Continue > Klik Rotation... > Pada kotak dialog Factor Analysis: Rotation tentukan Method yaitu Varimax $>$ Pada Display ceklis kotak Rotated Solution dan Loading Plot(s) > Maximum Iterations for Convergence tetap pada angka $25>$ Continue $>$ OK. 
Penjelasan variabel oleh faktor adalah seberapa besar faktor yang nantinya terbentuk mampu menjelaskan variabel. Untuk itu harus dilihat tabel Communalities (Santoso, 2006: 41). Setelah mengetahui bahwa faktor maksimal yang bisa terbentuk, selanjutnya melakukan penentuan masing-masing variabel independen akan masuk ke dalam setiap faktor. Cara menentukannya adalah dengan melihat tabel Component Matrix (Santoso, 2006: 45). Penentuan input variabel ke faktor tertentu melihat pada besaran korelasi antara variabel dengan faktor, yaitu pada korelasi yang terbesar.

\section{Hasil Penelitian dan Pembahasan}

Pengumpulan data di lima SMAN yang tersebar di lima wilayah Pembantu Bupati (eks kawedanan) dilaksanakan oleh 5 orang mahasiswa, dengan pengarah dan petunjukpetunjuk dari peneliti. Pelaksanaan pengisian koesioner oleh siswa responden sebagian besar dilaksanakan pada hari kedua setelah kedatangan para petugas di sekolah.

Koesioner yang digunakan dalam penelitian ini terdiri dari 79 butir, yang terdiri dari 4 butir mengungkap identitas responden, dan 75 butir pertanyaan mengungkap 15 variabel penelitian. Identitas responden meliputi: nomor urut kuesioner, kode sekolah, kode kelas, dan jenis kelamin. Jenis kelamin responden diberi label (1) untuk laki-laki, dan (2) untuk perempuan. Dari 75 butir pertanyaan setelah dikalibrasi terdapat 20 butir pertanyaan tidak valid karena sebaran data menyimpang dari distribsi normal dan 2 butir soal tidak valid karena memiliki nilai $\mathrm{KMO}<0,500$ sehingga digugurkan.

Pengujian normalitas distribusi skor setiap variabel berfungsi untuk menetapkan apakah data yang dikumpulkan layak untuk diolah dengan analisis faktor. Analisis faktor termasuk dalam kelompok statistika parametrik yang dilandasi asumsi bahwa sebaran skor variabel memiliki pola distribusi normal. Uji normalitas dikerjakan dengan menghitung koefisien kejulingan (skewness) dan keruncingan (kortusis) distribusi skor setiap variabel. Uji normalitas data dikerjakan terhadap 53 butir pertanyaan atau variabel yang diteliti.

Kejulingan (skewness) suatu kurva dapat dilihat dari perbedaan letak antara mean, median, dan modusnya. Jika ketiga ukuran pemusatan data tersebut berada pada titik yang sama, maka dikatakan simetris atau data berdistribusi normal; sedangkan jika tidak sama berarti data tidak simetris atau tidak berdistribusi normal. Ukuran kecondongan data terbagi atas tiga bagian, yaitu (1) kejulingan data ke arah kiri (negatif) apabila nilai modus lebih besar dari nilai mean, (2) kejulingan data simetris (distribusi normal) jika mean dan 
modus adalah sama; dan (3) kejulingan data ke arah kanan (positif) apabila nilai mean lebih besar dari nilai modus.

Keruncingan (kortusis) dinilai sebagai bentuk distorsi dari kurva normal. Tingkat keruncingan diukur dengan membandingkan bentuk keruncingan kurva distribusi data dengan kurva normal yang terbagi atas tiga yaitu (a) leptokurtic, yaitu apabila bagian tengah dari distribusi data memiliki puncak yang lebih runcing dengan nilai keruncingan lebih dari 3, (b) platykurtic, yaitu jika bagian tengah dari distribusi data memiliki puncak yang lebih datar dengan nilai keruncingan kurang dari 3, dan (c) mesokurtic, yaitu apabila bagian tengah dari distribusi data memiliki puncak di antara leptokurtic dan platykurtic dengan nilai keruncingan sama dengan 3,0.

Fungsi kedua, untuk menguji bahwa prosedur sampling yang dipilih dalam penelitian ini dapat dipertanggung jawabkan. Konsekuensi dari pengujian ini kepada tingginya prediktivitas hasil penelitian ini. Bila distribusi skor tiap variabel penelitian tidak menyimpang dari sebaran normal, maka hasil analisis statistikaknya dapat digeneralisasikan kepada populasi yakni seluruh siswa SMAN di kabupaten Klaten; sebaliknya jika sebaran data setiap variabel penelitian distribusinya tidak normal, maka hasil analisis statistikanya hanya dapat disimpulkan kepada sampel penelitian saja; yakni 304 siswa SMA sebagaimana disebutkan sebelumnya.

Data penelitian ini telah diuji distribusi normalitas dengan kriteria apabila memiliki koefisien kejulingan (skewness) berkisar antar -2,000 sampai + 2,000 dengan keruncingan (kortusis) kurang dari 2,000. Dengan kriteria tersebut di atas, ditemukan 20 sebaran data yang menyimpang dari sebaran normal yakni variabel nomor: 2, 9, 18, 21, 23, 31, 36, 39, $42,43,44,45,47,54,61,63,64,65,68$, dan nomor 74. Keduapuluh variabel tersebut digugurkan dan tidak disertakan dalam analisis faktor karena tidak memenuhi persyaratan.

Berdasarkan hasil perhitungan kejulingan dan kortusis, ada sejumlah variabel yang mirip yakni variabel nomor 28 (objektif) dengan nomor 34 (memberi nilai secara objektif) dan 39 (memberi nilai secara adil). Demikian pula variabel nomor 32 (humoris) dan variabel nomor 45 (diselingi humor waktu mengajar); sehingga bisa digugurkan salah satu sehingga hanya 41 (empat puluh satu) variabel ciri perilaku guru SMA yang disenangi oleh siswanya; terdiri dari 12 (dua belas) ciri tidak dikehendaki, dan 29 (dua puluh sembilan) ciri perilaku yang Dikehendaki.

Analisis data melalui analisis faktor dilakukan 2 (dua) kali, yakni (1) analisis faktor terhadap 27 (dua puluh tujuh) variabel ciri perlaku guru yang dikehendaki dan (2) analisis 
faktor terhadap 12 (dua belas) variabel ciri perilaku guru yang Tidak Dikehendaki. Tujuannya adalah untuk mengidentifikasi variabel-variabel mana saja yang merupakan ciri perilaku guru SMA yang dikehendaki oleh siswanya, dilanjutkan dengan pengelompokan variabel-variabel tersebut ke dalam sejumlah faktor yang saling tidak tumpang tindih. Setelah itu dilanjutkan analisis faktor untuk mengidentifikasi variabel-variabel mana saja ciri perilaku guru SMA yang Tidak dikehendaki oleh siswanya.

Dalam penelitian ini ditemukan 27 (dua puluh tujuh) ciri perilaku guru yang dikehendaki oleh siswanya yaitu guru yang (1) rajin hadir di sekolah, (2) mudah ditemui di sekolah, (3) menegakkan disiplin, (4) menjaga ketertiban sekolah, (5) suka menasihati, (6) wajah ceria, (7) supel atau komunikatif, (8) berterus terang, (9) berpenampilan rapi, (10) menyukai keteraturan, (11) aktif dalam kegiatan sekolah, (12) optimistik, (13) menyukai perubahan, (14) sabar, (15) humoris, (16) membahas soal-soal yang sulit, (17) menguasai materi pelajaran, (18) menerapkan berbagai metode, (19) mengaktifkan siswa, (20) terampil dalam mengajar, (21) perhatian, (22) bekerja dengan teliti, (23) hati-hati, (24) suka hemat, (25) menampung keluhan siswa, (26) jarang memberi tugas, dan (27) suaranya jelas (lampiran-4).

Hasil analisis faktor diperoleh nilai KMO (Kaiser-Meyer-Olkin) untuk 29 variabel ciri perilaku guru yang dikehendaki siswa sebesar 0,823 (di atas 0,500) dengan indeks komunalitas mencapai 1,000 sehingga bisa dipertanggungjawabkan secara metodologis. Ke-27 ciri variabel perilaku guru SMA yang dikehendaki oleh siswa tersebut setelah dilakukan ekstraksi dengan metode Analisis Komponen Utama (Principal Component Analysis) dilanjutkan dengan rotasi dengan metode Varimax secara normalisasi Kaiser dapat dikelompokkan menjadi 8 (delapan) faktor yang tidak saling tumpang tindih.

Faktor-1 memuat 3 variabel yakni variabel nomor-23 (Bekerja dengan teliti), nomor 24 (Bekerja dengan tekun), dan variabel nomor 25 (Bekerja dengan hemat). Faktor-2 memuat 4 variabel yakni variabel-variabel nomor-1 (Rajin datang ke sekolah), nomor-2 (Mudah ditemui di sekolah), nomor-3 (Menegakkan disiplin sekolah), dan variabel nomor4 (Menegakkan ketertiban sekolah). Faktor-3 memuat 4 variabel yaitu variabel nomor-6 (Tampil ceria), nomor-7 (Supel atau komunikatif), nomor-13 (Menerima perubahan), dan variabel nomor 14 (Sabar). Faktor-4 memuat 3 variabel yaitu nomor 5 (Suka menasihati), nomor 10 (Suka keteraturan), dan nomor-22 (Perhatian). Faktor-5 terdiri dari 4 variabel yakni variabel nomor-16 (Membahas soal yang sulit), nomor-17 (Memberi nilai secara objektif), nomor-18 (Menguasai matetri pelajaran), dan nomor-19 (Menerapkan metode 
yang bervariasi). Faktor-6 memuat 3 variabel yakni variabel nomor-15 (Humoris), nomor 26 (Menampung keluhan), dan nomor 27 (Berbicara dengan suara yang jelas).

Tabel-5. Matriks Pola Faktor Ciri Perilaku Guru yang Dikehendaki Siswa

\begin{tabular}{|c|c|c|c|c|c|c|c|c|c|}
\hline No. & Variabel & Fak-1 & Fak-2 & Fak-3 & Fak-4 & Fak-5 & Fak-6 & Fak-7 & Fak-8 \\
\hline 1. & Rajin & $-0,103$ & 0,292 & $-0,110$ & 0,067 & $-0,043$ & $-0,082$ & 0,044 & 0,176 \\
\hline 2. & Ditemui & $-0,068$ & 0,346 & 0,100 & 0,043 & $-0,212$ & 0,229 & $-0,209$ & $-0,032$ \\
\hline 3. & Disiplin & 0,000 & 0,339 & $-0,051$ & $-0,063$ & 0,099 & $-0,060$ & $-0,035$ & $-0,092$ \\
\hline 4. & Tertib & 0,015 & 0,337 & 0,008 & $-0,119$ & 0,023 & $-0,065$ & 0,075 & $-0,139$ \\
\hline 5. & Nasihati & $-0,056$ & $-0,251$ & $-0,071$ & 0,422 & 0,029 & 0,061 & 0,001 & $-0,018$ \\
\hline 6. & Ceria & $-0,068$ & 0,022 & 0,410 & $-0,017$ & $-0,043$ & $-0,004$ & $-0,201$ & 0,191 \\
\hline 7. & Komunikatif & $-0,114$ & $-0,011$ & 0,442 & 0,064 & 0,020 & $-0,133$ & 0,135 & $-0,129$ \\
\hline 8. & Terus terang & $-0,121$ & $-0,050$ & 0,017 & 0,088 & $-0,123$ & 0,029 & 0,048 & 0,526 \\
\hline 9. & Rapi & 0,126 & $-0,033$ & $-0,020$ & $-0,019$ & 0,091 & $-0,159$ & $-0,071$ & 0,484 \\
\hline 10. & Teratur & $-0,109$ & 0,003 & $-0,051$ & 0,408 & 0,063 & $-0,181$ & 0,033 & 0,072 \\
\hline 11. & Aktif & $-0,038$ & $-0,069$ & $-0,143$ & $-0,012$ & 0,019 & $-0,022$ & 0,544 & 0,048 \\
\hline 12. & Optimis & 0,028 & 0,013 & 0,001 & $-0,068$ & $-0,002$ & 0,034 & 0,307 & 0,066 \\
\hline 13. & Modern & 0,033 & 0,047 & 0,239 & $-0,056$ & $-0,224$ & 0,004 & 0,403 & $-0,209$ \\
\hline 14. & Sabar & 0,060 & $-0,188$ & 0,244 & $-0,091$ & 0,119 & $-0,010$ & $-0,038$ & 0,143 \\
\hline 15. & Humoris & $-0,015$ & $-0,007$ & 0,166 & $-0,082$ & $-0,061$ & 0,371 & $-0,103$ & $-0,108$ \\
\hline 16. & Bahas soal & $-0,139$ & $-0,063$ & 0,002 & 0,147 & 0,513 & $-0,103$ & $-0,058$ & $-0,112$ \\
\hline 17. & Nilai adil & $-0,043$ & 0,005 & $-0,048$ & $-0,040$ & 0,343 & 0,100 & $-0,053$ & 0,029 \\
\hline 18. & Kuasai & $-0,006$ & 0,088 & $-0,054$ & $-0,197$ & 0,335 & 0,052 & 0,050 & 0,043 \\
\hline 19. & Metode & 0,162 & $-0,033$ & 0,001 & $-0,013$ & 0,171 & $-0,040$ & $-0,086$ & $-0,002$ \\
\hline 20. & Aktifkan & 0,058 & $-0,033$ & 0,022 & 0,257 & $-0,144$ & 0,078 & $-0,009$ & 0,054 \\
\hline 21. & Terampil & 0,090 & $-0,019$ & $-0,018$ & 0,130 & 0,123 & 0,071 & $-0,046$ & $-0,144$ \\
\hline 22. & Perhatian & $-0,038$ & 0,079 & 0,094 & 0,437 & $-0,058$ & $-0,053$ & $-0,181$ & $-0,075$ \\
\hline 23. & Teliti & 0,357 & $-0,005$ & $-0,160$ & $-0,098$ & $-0,140$ & 0,094 & $-0,009$ & 0,050 \\
\hline 24. & Tekun & 0,354 & $-0,066$ & $-0,118$ & $-0,027$ & $-0,052$ & $-0,037$ & 0,013 & 0,037 \\
\hline 25. & Hemat & 0,341 & $-0,020$ & 0,101 & $-0,089$ & $-0,084$ & $-0,168$ & 0,073 & $-0,182$ \\
\hline 26. & Tampung & $-0,104$ & $-0,007$ & $-0,017$ & 0,004 & $-0,007$ & 0,406 & 0,092 & $-0,075$ \\
\hline 27. & Suara jelas & 0,029 & $-0,057$ & $-0,240$ & $-0,042$ & 0,033 & 0,452 & $-0,003$ & 0,085 \\
\hline
\end{tabular}

Catatan: Muatan faktor (factor loading) ditandai pada koefisien yang tertinggi

Faktor-7 memuat 2 variabel yaitu nomor 11 (Aktif dalam kegiatan di sekolah), dan nomor 12 (Optimis). Faktor-8 memuat 2 variabel yaitu nomor 8 (Berterus terang) dan nomor-9 (Tampil rapi).

Dua belas ciri perilaku guru yang Tidak Dikehendaki oleh siswanya yaitu guru yang (1) sering terlambat, (2) masuk sekolah hanya waktu mengajar, (3) dekat dengan siswa tertentu saja, (4) sering menyidir siswa, (5) sering khawatir dan cemas, (6) mudah tersinggung, (7) memberi tes secara mendadak, (8) sering atau banyak duduk di kursi guru, (9) marah jika sering ditanya, (10) menjaga jarak dengan siswa, (11) tampilan menakutkan, dan (12) sering memberi hukuman kepada siswa (Lampiran-5).

Hasil analisis faktor diperoleh nilai KMO (Kaiser-Meyer-Olkin) untuk 12 variabel ciri perilaku guru yang Tidak dikehendaki siswa sebesar 0,746 (di atas 0,500) dengan 
indeks komunalitas 1,000 sehingga bisa dipertanggungjawabkan secara metodologis. Ke12 ciri variabel perilaku guru yang Tidak dikehendaki siswa tersebut setelah dilakukan ekstraksi dengan metode Analisis Komponen Utama (Principal Component Analysis) dilanjutkan dengan rotasi dengan metode Varimax dapat dikelompokkan menjadi 4 (empat) faktor yang tidak saling tumpang tindih sebagaimana tampak pada Tabel-6.

Tabel-6. Matriks Pola Faktor Ciri Perilaku Guru yang Tidak Dikehendaki Siswa

\begin{tabular}{|c|l|r|r|r|r|}
\hline No. & \multicolumn{1}{|c|}{ Variabel } & Fak-1 & \multicolumn{1}{c|}{ Fak-2 } & Fak-3 & Fak-4 \\
\hline 1. & Terlambat masuk kelas & 0,184 & $-0,076$ & $-0,081$ & 0,438 \\
\hline 2. & Ke sekolah jk terjadwal & 0,128 & 0,003 & $-0,058$ & $-0,707$ \\
\hline 3. & Dekat siswa tertentu & 0,386 & $-0,024$ & $-0,165$ & $-0,112$ \\
\hline 4. & Sering menyindir & 0,315 & $-0,089$ & 0,148 & 0,045 \\
\hline 5. & Pesimistis & 0,196 & $-0,005$ & $-0,054$ & 0,225 \\
\hline 6. & Mudah tersinggung & 0,390 & $-0,115$ & 0,086 & $-0,067$ \\
\hline 7. & Lakukan tes mendadak & 0,114 & $-0,140$ & 0,569 & $-0,040$ \\
\hline 8. & Sering duduk di kursi & 0,146 & 0,250 & 0,372 & $-0,231$ \\
\hline 9. & Marah jika ditanya & 0,002 & 0,434 & $-0,153$ & $-0,065$ \\
\hline 10. & Menjaga jarak dg siswa & $-0,185$ & 0,409 & 0,064 & 0,212 \\
\hline 11. & Penampilan seramkan & $-0,061$ & 0,400 & 0,129 & $-0,065$ \\
\hline 12. & Sering menghukum & $-0,134$ & 0,184 & 0,463 & $-0,022$ \\
\hline
\end{tabular}

Catatan: Muatan faktor (factor loading) ditandai pada koefisien yang tertinggi

Dengan mencermati hasil analisis pada Tabel-6 tampak bahwa dari 12 variabel ciri perilaku guru yang Tidak dikehendaki oleh siswanya dapat dikelompokkan ke dalam 4 faktor yang saling tidak tumpang tindih. Faktor-1 memuat 4 variabel yakni (1) Ke sekolah hanya jika ada jadwal mengajar, (2) Dekat hanya dengan siswa tertentu, (3) Sering menyindir siswa, dan (4) Mudah tersinggung. Faktor-2 memuat 3 variabel yaitu (1) Marah jika ditanya siswa, (2) Menjaga jarak dengan siswa, dan (3) Penampilan menyeramkan. Faktor-3 memuat 3 variabel yaitu (1) Melaksanakan tes secara mendadak, (2) Sering duduk di kursi guru, dan (3) Sering menghukum. Faktor-4 memuat 2 variabel yaitu (1) Terlambat masuk ke dalam kelas, dan (2) Pesimistis. Secara kumulatif ke-4 faktor tersebut mampu menjelaskan 52,77\% ciri perilaku guru yang Tidak dikehendaki siswa dengan rincian faktor-1 sebesar $16,99 \%$, faktor-2 sebesar $14,76 \%$, faktor-3 sebesar $11,10 \%$ dan faktor-4 sebesar $9,91 \%$.

Hasil analisis faktor terhadap 304 responden siswa SMA yang tersebar di 15 kelas dalam penelitian ini menemukan ada 27 variabel ciri perilaku guru SMA yang dikehendaki oleh siswanya dan ada 12 ciri perilaku guru yang Tidak dikehendaki siswanya. Selanjutnya dari 27 variabel ciri perilaku guru yang Dikehendaki siswa tersebut ternyata dapat 
dikelompokkan menjadi 8 faktor yang tidak saling tumpang tindih. Demikian pula dari 12 variabel ciri perilaku guru yang Tidak dikehendaki siswanya dapat diklasterkan ke dalam 4 faktor yang tidak saling tumpang tindih; sehingga langkah terakhir dari analisis faktor adalah proses memberikan nama terhadap 8 faktor perilaku guru yang dikehendaki oleh siswanya dan 4 faktor perilaku guru yang Tidak dikehendaki oleh siswanya.

Pengelompokan dan penamaan beberapa variabel ke dalam suatu faktor, bisa didekati dengan dua cara, yakni pengelompokan atas dasar angka koefisien korelasi yang terbesar, dan pengelompokan atas dasar angka koefisien korelasi yang signifikan. Setelah disimulasikan kedua cara tersebut dalam penelitian ini ternyata menghasilkan pengelompokan variabel ke dalam faktor yang sama.

Berdasarkan koefisien korelasi yang lebih terbesar, ternyata faktor-1 mencakup variabel-variabel: bekerja dengan teliti, bekerja dengan tekun, dan bekerja dengan hemat yang semuanya menunjukkan koefisien korelasi positif dan signifikan pada $\alpha<0,05$ (antara 0,341 sampai dengan 0,357). Dengan mencermati ciri pokok yang melekat pada variabel-variabel tersebut, maka faktor-1 diberi nama dengan Tekun.

Untuk faktor-2 mencakup empat variabel yaitu: rajin datang ke sekolah, mudah ditemui di sekolah, menegakkan disiplin, dan menegakkan ketertiban; yang kesemuannya berkorelasi positif dan signifikan pada $\alpha<0,05$ (antara 0,292 sampai dengan 0,346). Keempat variabel yang terkelompok dalam faktor-2 diberi nama Disiplin.

Faktor-3, ternyata meliputi variable-variabel: Tampil ceria, komunikatif, modern, dan sabar dengan koefisien korelasi positif dan signifikan pada $\alpha<0,05$ (antara 0,244 sampai dengan 0,442) sehingga diberi nama Modern.

Faktor-4 memuat variabel-variabel: sering menasihati siswa, teratur, dan memberikan perhatian kepada siswa. Ketiga variabel tersebut memiliki koefisien korelasi positif dan signifikan pada $\alpha<0,05$ (antara 0,408 sampai 0,437) dan diberi nama Perhatian.

Faktor-5 mencakup variabel-variabel: membahas soal-soal yang sulit, memberi nilai secara objektif, menguasai materi pelajaran, dan menerapkan berbagai metode pembelajaran. Keempat variabel ini berkorelasi positif dan signifikan pada $\alpha<0,005$ (antara 0,171 sampai 0,523). Karena keempat variabel tersebut terkait dengan tugas pokok guru di kelas dalam proses pembelajaran, faktor-5 diberi nama Profesional. 
Faktor-6 memuat variabel-variabel: humoris, menampung keluhan siswa, dan suaranya jelas. Ketiga variabel ini juga saling berkorelasi positif dan signifikan pada $\alpha<$ 0,05 (antara 0,371 sampai 0,452), diberi nama Humoris.

Faktor-7 hanya terdiri dari dua variabel yakni: berperan aktif dalam kegiatan di sekolah dan optimis masing-masing memiliki koefisien korelasi 0,544 dan 0,307 (signifikan pada $\alpha<0,05$ ) pantas jika diberi nama Aktif.

Faktor-8 memuat dua variabel ciri perilaku guru yang dikehendaki oleh siswanya yaitu: berterus terang dan tampil rapi. Kedua variabel ini memiliki koefisien korelasi positif dan signifikan pada $\alpha<0,05$ yaitu: 0,526 dan 0,484 yang diberi nama Tampil rapi.

Dengan demikian disimpulkan bahwa terdapat delapan faktor yang memuat 27 variabel ciri-ciri perilaku guru yang dikehendaki oleh siswanya, yakni: (1) tekun, (2) disiplin, (3) modern, (4) perhatian, (5) profesional, (6) humoris, (7) aktif, dan (8) tampil rapi.

Berdasarkan hasil analisis data melalui SPSS, penelitian ini juga menemukan ada 12 (dua belas) variabel ciri perilaku guru yang Tidak dikehendaki oleh siswanya yang dapat diklasterkan ke dalam 4 (empat) faktor.

Faktor-1 memuat variabel-variabel: datang ke sekolah hanya jika punya jadwal mengajar, dekat hanya dengan siswa tertentu, sering menyindir siswa, dan mudah tersinggung. Keempat variabel tersebut memiliki koefisien korelasi positif dan signifikan pada $\alpha<0,05$ (antara 0,128 sampai dengan 0,390) diberi nama Pemalas.

Faktor-2 terdiri dari tiga variabel yakni: marah jika ditanya, menjaga jarak dengan siswa, dan berpenampilan menyeramkan dengan koefisen korelasi positif dan signifikan pada $\alpha<0,05$ (antara 0,400 sampai dengan 0,434) diberi nama Pemarah.

Faktor-3 memuat tiga variabel yaitu: melakukan tes secara mendadak, banyak duduk di kursi guru, dan sering memberi hukuman kepada siswa. Ketiga variabel ini berkorelasi positif dan signifikan pada $\alpha<0,05$ (antara 0,372 sampai 0,569) diberi nama Sering Menghukum.

Faktor-4 ciri perilaku yang Tidak dikehendaki oleh siswanya mencakup variabelvariabel: sering terlambat masuk ke kelas, dan pesimistik. Kedua variabel ini juga memiliki koefisien korelasi positif dan signifikan pada $\alpha<0,05$ (antara 0,225 sampai 0,438) diberi nama Sering terlambat. 
Dengan demikian disimpulkan bahwa terdapat empat faktor yang memuat 12 variabel ciri-ciri perilaku guru yang Tidak dikehendaki oleh siswanya, yakni: (1) pemalas, (2) pemarah, (3) sering menghukum, dan (4) sering terlambat.

\section{Kesimpulan}

Berdasarkan hasil analisis, dapat dikemukakan simpulan pokok dan penting dari penelitian ini sebagai berikut.

1. Terdapat dua puluh tujuh variabel ciri perilaku guru SMA di kabupaten Klaten yang Dikehendaki oleh siswanya yaitu guru yang guru yang (1) rajin hadir di sekolah, (2) mudah ditemui di sekolah, (3) menegakkan disiplin, (4) menjaga ketertiban sekolah, (5) suka menasihati, (6) wajah ceria, (7) supel atau komunikatif, (8) berterus terang, (9) berpenampilan rapi, (10) menyukai keteraturan, (11) aktif dalam kegiatan sekolah, (12) optimistik, (13) menyukai perubahan, (14) sabar, (15) humoris, (16) membahas soalsoal yang sulit, (17) menguasai materi pelajaran, (18) menerapkan berbagai metode, (19) mengaktifkan siswa, (20) terampil dalam mengajar, (21) perhatian, (22) bekerja dengan teliti, (23) hati-hati, (24) suka hemat, (25) menampung keluhan siswa, (26) jarang memberi tugas, dan (27) suaranya jelas. Dengan demikian hipotesis-2 Ditolak.

2. Ke-27 variabel ciri perilaku guru SMA yang Dikehendaki oleh siswanya sebagaimana disebutkan pada butir pertama dapat dikelompokkan menjadi 8 (delapan) faktor, yakni: (1) tekun, (2) disiplin, (3) modern, (4) perhatian, (5) profesional, (6) humoris, (7) aktif, dan (8) tampil rapi.

3. Terdapat dua belas variabel ciri perilaku guru SMA di Kabupaten Klaten yang Tidak dikehendaki oleh siswanya yaitu guru yang (1) sering terlambat, (2) masuk sekolah hanya waktu mengajar, (3) dekat dengan siswa tertentu saja, (4) sering menyidir siswa, (5) sering khawatir dan cemas, (6) mudah tersinggung, (7) memberi tes secara mendadak, (8) sering atau banyak duduk di kursi guru, (9) marah jika sering ditanya, (10) menjaga jarak dengan siswa, (11) tampilan menakutkan, dan (12) sering memberi hukuman kepada siswa.

4. Ke-12 variabel ciri perilaku guru yang Tidak dikehendaki oleh siswanya sebagaimana disebut pada butir ketiga dapat dikelompokkan ke dalam empat faktor yakni: (1) pemalas, (2) pemarah, (3) sering menghukum, dan (4) sering terlambat. 
Beberapa saran yang dapat dikemukakan berdasarkan hasil penelitian ini untuk dapat memaksimalkan hasil penelitian ialah.

Pertama, pembinaan dan peningkatan terhadap kedisiplinan, dan kemampuan akademik guru masih perlu lebih ditingkatkan baik frekuensi maupun kualitasnya.

Kedua, untuk pengangkatan atau pengadaan guru,hendaknya diidentifikasi statusnya berdasarkan kriteria ke-dua belas faktor yang terungkap melalui penelitian ini, yakni faktor: ketekunan, kedisiplinan, modernitas, perhatian, keprofesionalan, humoris, aktivitas, dan penampilan (aspek positif) serta kemalasan, sifat mudah marah, keseringan memberi hukuman, dan keterlambata (aspek negatif).

Ketiga, kebijakan pembinaan dan pengembangan kompetensi guru melalui PLPG hendaknya mempertimbangkan proporsi peranan ke-12 faktor yang ditemukan melalui penelitian ini yang menggambarkan ciri perilaku guru yang dikehendaki maupun yang tidak dikehendaki oleh para siswannya.

Demikian beberapa pokok pikiran yang bisa diungkapkan dari hasilpenelitian itu, dengan segala kekurangan dan kelemahnnya hasil penelitian ini kiranya dapat bermanfaat bagi pembinaan, dan pedoman pengadaan guru di Indonesia agar diperoleh guru-guru yang memiliki dedikasi dan kedisiplinan tinggi, kemampuan intelektual yang baik, dengan penampilan pribadi yang sesuai, serta guru yang dekat pada siswannya sehingga secara tulus bersedia membantu kesulitan siswa. Hanya dari guru-guru yang memiliki ciri-ciri tersebutlah, bisa dihasilkan manusia-manusia pembangunan Indonesia yang mampu membangun dirinya sendiri dan secara bersama-sama mampu membangun bangsanya.

\section{Daftar Pustaka}

Bany, M. A, dan Johnson, L.V. (1975). Educational Social Psychology. New York: Macmillan Publishing.

Biddle, B.J., dan Ellena, W. J. (1974). Contemporary Research on Teacher Effectiveness. New York: Holt Rinehart and Wiston.

Comrey, A. L.A. (1973). First Course in Factor Analysis. New York: Academic Press.

Crider, A. B. et.al. (1983). Psychology. Dallas Texas: Scott, Foresman and Co.

Flippo, E.B. (1976). Principle of Personal Management. Tokyo: McGraw-Hill Kogakusha.

Good, L.J., dan Brophy,J.E. (1973). Looking Worker. New York: Harper and Raw Publishers. 
Gordon, I. J. (1956). The Teacher as A Guidance Worker. New York: Harper and Raw Publishers.

Kerlinger, F.N. (1990). Asas-asas Penelitian Behavioral. Terjemahan L.R. Simatupang. Yogyakarta: Gadjah Mada University Press.

Krecjie,R.V., dan Morgan, D.W. (1970). "Determining Sampel Size for Research Activities", in Educational and Psychological Measurument. Vol. 30, pp. 70-79

Murray, H.G., Rushaton, J.F., and Paunonen, S.V. (1990). 'Teacher Personality Traits and Student Instrutional Rantings in Six Tipes Of University Courses", in Journal of Educational Psychology. Vol.82, No.2, pp. 198-206.

Nash, R. (1974). "Pupil's Ekspectations for Their Teacher", in Research in Education. Vol.12, pp. 197-207.

Reilly, R. R. , and Lewis, E. L. (1981). Educational Psychology: Applications for Classroom Learning and Instruction. New York :Macmillan Co.

Ryans, D.G. (1960). Characteristic Teacher, Their Describtion, Comparations, and Appraisal. Washington DC: American Council on Education.

Sofyan Yamin dan Heri Kurniawan. (2014). SPSS Complete: Teknik Analisis Statistik Terlengkap dengan Software SPSS. Jakarta: Salemba Infotek.

Suryanto. (1988). Metode Statistika Multiviate. Jakarta: Dekdikbud.

Tabachnick, B.G. and Fidell, L.S. (1983). Using Multivariate Statistics. New York: Harper and Raw Publishers.

Winarno Surachman. (1969). Guru dan Pendidikannya. Jakarta: Depdikbud. 